\title{
DOI 10.26886/2520-7474.5(31)2018.10
}

UDK: 780.647.2.09(072) + 78.071.1(477)

\section{BOBICH INSTRUMENTAL CREATIVITY: METHODOLOGICAL AND EXECUTIVE ASPECTS}

\section{P. Shymanskyi, PhD, Associate Professor \\ V. Kucheruk, Assistant Professor}

East European National University named after Lesia Ukrainka, Lutsk

In this article the key aspects of our contemporary Davor Bobitch's famous and often performed composer in Europe are discussed in the great musical, pedagogical, performing and cultural activities of society, to the great sorrow of almost unknown in our fields. There are no publications about the composer in Ukraine, no published or analyzed his works. From this review, information about the composer and analysis of his sonatas can be a step in the interest of our performers and musicologists, in particular his accordion work.

Key words: Davor Bobych, composer activity, pedagogical repertoire, accordion performance, chamber-instrumental music.

П. Шиманський, доктор фрілософії; В. Кучерук, дочент, Інструментальна творчість Д. Бобіча: методико-виконавський аспект/ Східноєвропейський національний університет імені Лесі Українки, Україна, Луцьк

У даній статmі розглянуті ключові аспекти музичнопедагогічної, виконавської та культурно-громадської діяльності нашого сучасника Давора Бобіча відомого $і$ часто виконуваного $в$ Європі композитора, на превеликий жаль майже не знаного на наших теренах. В Україні немає публікацій про композитора, не видавались та не аналізувались його твори. 3 цього огляду інфрормація про композитора та аналіз його сонати може стати кроком до 
зацікавлення нашими виконавцями та музикознавцями, зокрема його акордеонним доробком

Ключові слова: Давор Бобіч, композиторська діяльність, педагогічний репертуар, акордеонне виконавство, камерноінструментальна музика.

Стрімка еволюція баянного мистецтва, яка обумовлена вдосконаленням технічних можливостей інструмента, спричинила активний розвиток виконавства та появу широкого, різноманітного за жанрами та стилями сучасного оригінального репертуару. «Баян не $є$ табу для композитора, він не $є$ недосконалим інструментом, блідою копією органа чи «пневматичним ящиком», придатним тільки для легкої музики. Це інструмент із самостійними правами, із власним незалежним потенціалом і тільки йому притаманними технічними вимогами, подібно до будь-яких інших музичних інструментів» - ці слова сучасного фрінського композитора Е. Йокінена у стислій формі передають суть розвитку баянного репертуару у XX столітті $[7,172]$.

У другій половині минулого століття завдяки індивідуальному втіленню сучасних засобів музичної мови баян виступає як самобутній інструмент, що має великі потенційні можливості для розвитку у професійній камерно-інструментальній сфрері музичного мистецтва. Багатство ресурсів і самобутність привабили до роботи для баяна талановитих композиторів, що створили велику кількість творів високого художнього ґатунку, що за своїм естетичним рівнем не поступаються кращим зразкам традиційного світового інструментального репертуару.

Музична література XX-поч. XXI століття має цілий ряд авторів, що створювали оригінальний репертуар для баяна. Серед європейських авторів виділимо Г. Бреме, Т. Лундквіста, Л. Беріо, Пауля 
Ровзінга Ольсена, В. Якобі, К. Швена, В.Трояна, П. Макконена, О. Шмідта, Б. Довлаша, А. Кшановского, Л. Кайзера, К. Ахо, Ю. Такахаші, Т. Хосокави. Найяскравішими представниками російської композиторської школи тут можна назвати В. Золотарьова, О. Холмінова. С. Губайдуліну, Е. Денісова, А. Кусякова, Г. Банщикова, С. Беринського. Своєрідним відкриттям інструмента заново стала п'єса С. Губайдуліної "De Profundis" (1978). Останню свою річ "Світло в пітьмі" Едісон Денісов написав також для баяна. Блискучі зразки творів для баяна створили й українські композитори В. Зубицький, В. Рунчак, В. Бібік, В. Балик, В. Дікусаров, В. Власов, В. Довгань, А. Гайденко.

В жанрі естрадної мініатюри працювали П. Фросіні, П'єтро і Гвідо Дейро, Арт Ван Дамм, Ф. Марокко, Р. Вюртнер, А. Фоссен, М. Азола, Рішар Гальяно та інші популярні у всьому світі музиканти, які $є$ не лише видатними виконавцями, але й авторами багатьох яскравих і талановитих творів. Окремо стоїть творчість Астора П'яццоли, видатного виконавця на бандонеоні. Хоча свої твори він писав як правило для бандонеона, вони отримали популярність саме в звучанні баяна та акордеона [2, 304].

Цим композиторам належить відкриття епохи «нового баяна», співзвучного звуковим ідеям сучасності. Зруйнувавши стереотип традиційного розуміння цього інструмента як придатного тільки для створення «мелодизованих» творів, композиторами була відкрита нова сучасна музична лексика інструменту.

Пошуки темброфактурних прийомів ішли шляхом створення об'ємних просторових звучань: незліченних комбінацій мелодія-фрон, специфічно баянних дублювань мелодій (консонуючих, дисонуючих, інтервальних, акордових), накладання пластів фрактури. Росла поліфонізація всіх видів музичного викладу. У фрактурі, а також і в гармонії, динаміці наряду з функціональністю щораз більше місце 
займала колористичність. Різкі контрасти гучності, тонка робота 3 динамічним рівнем цілих композицій і навіть окремих звуків і співзвуч не зстосовувались в музиці до цього часу. Оновлення тембрової палітри пов'язано також із широким развитком сонорних елементів (кластерів, вібрато, гліссандо, тремоло міхом, рикошета), яким відводиться важлива композиційна і колористична роль [5, 35].

Характерні зміни в образному ладі відбулися в бік поглиблення психологічних і трагічних образів у поєднанні з підвищеною експресією звучання. Поєднання конфрліктності з образами сарказму, іронії, 3 глибокою суворої скорботою - все це тенденції, характерні як для баянного інструменталізму, так і для всього вітчизняного камерноінструментального мистецтва $[1,61]$.

Давор Бобіч $€$ одним з найяскравіших сучасних композиторів Хорватії та всієї Східної Європи, що сформувалися як митці у 80-90-х роках XX ст. Він знаний не лише на батьківщині, але й за ії межами. Прем'єри його творів - значні події в музичному житті країни. Він член Хорватської спілки композиторів з 1994 року. Окрім цього митець займається педагогічною діяльністю, є одним із активних організаторів культурного життя Хорватії.

Давор Бобіч народився 1968 року у древньому місті Вараждин на північному заході Хорватії (на той час Югославії), нині великому промисловому центрі країни. Отримав базову музичну освіту в спеціалізованому коледжі рідного міста. Згодом його музичні шляхи пролягли до Києва, де він навчався в Київській державній консерваторії ім. П. І. Чайковського по класу композиції Г. І. Ляшенка, акордеона І. Д. Яшкевича. Молодий композитор був нагороджений відзнакою Міністерства культури України, як кращий іноземний студент 1992-93 років. 
Після повернення на батьківщину Давор Бобіч розпочав свою активну творчу та педагогічну діяльність. Він заснував клас композиції в музичній школі першого та другого ступенів рідного Вараждина вперше в історії Хорватської республіки. У 1999 р. Д. Бобіч став директором публічного інституту культури концертного бюро Вараждина. У 2003 р. він - старший викладач, в 2008 р. - доцент, а в 2009 р. - віце-декан в Академії мистецтв в Осієку.

Окремої уваги заслуговує участь, а згодом і керівництво Д. Бобічем відомим у Європі фестивалем «Барокові вечори» у Вараждині, що їх проводить Хорватське міністерство культури. Цей музичний фрорум $€$ однією з найголовніших мистецьких акцій міста й приваблює щороку тисячі туристів-меломанів не лише з Хорватії, але й з усього світу. У 1999, після смерті академіка Ю. Мурная, Д. Бобіч став членом комітету цього престижного національного фестивалю. У жовтні 2006 він був названий директором «Барокових вечорів» у Вараждині.

Інтенсивна композиторська та організаторська діяльність Давора Бобіча отримала широке визнання:

1996 р. - став володарем нагороди "Ivo Vuljević" як найуспішніший молодий хорватський музикант (він став першим композитором, що отримав цю престижну національну нагороду);

1998 р. - премія "Stjepan Šulek" за кращий оркестровий твір молодого композитора та нагороду від області Вараждин за виняткові досягнення в галузі культури;

У 2006 та 2007 роках - відзнака Міністерства культури Республіки Хорватія за популяризацію хорватської музики;

2008 р. - престижна нагорода Бориса Попандопуло;

найвищі нагороди у конкурсах на кращий твір хорової музики протягом кількох років. 
Наразі Д. Бобіч і сам є членом журі різних мистецьких премій і нагород, зокрема "Lukačić" i "Murai".

Досить численні опуси композитора - постійний елемент педагогічного репертуару у престижних мистецьких вузах Лондона, Хельсінкі, Києва, Мінська, Загреба та Осієка. Концертні твори митця є часто виконуваними по всьому світу провідними хорватськими та зарубіжними музикантами, ансамблями та оркестрами. Він постійно відвідує виконання своїх творів на усіх престижних фрестивалях країни.

Широку увагу мистецької публіки привернула його ораторія «Король Томіслав», а виконання «Вуковарського реквієма» у 2004 році було названо однією з головних музичних подій сезону. 3 ансамблем «Ладо» та хореографом Дінко Богданічем вони поставили балет 3 вокалом «Вероніка Десінічка». Твір завершив так звану «Національну трилогію», що мала надзвичайний успіх. Ораторія "Isaac" стала одним із головних проектів 2009 року у відзначенні міста Пеш як культурної столиці Європи [9].

Композиторська діяльність ще досить молодого композитора $є$ доволі плідною - творчий доробок нараховує більш ніж 150 творів різноманітних жанрів - від фортепіанних мініатюр, обробок народних пісень і до великих вокально-симфонічних полотен. При побіжному погляді на список творів звертає на себе увагу часте використання барокових жанрів (концерт, сюїта, ораторія), що дозволяє говорити про неокласичні риси його творчості. Поряд бачимо і твори в жанрах романтичної доби - поема, елегія, увертюра. $€$ у його доробку приклади жанрового синтезу, характерного для XX та початку XXI століття: елегія-концерт, поема-концерт, а також типові для цього періоду експерименти зі складами виконавців - пошуки нових звучностей, тембрових поєднань (Концерт для труби, струнних і дзвонів, «Озорські враження» для сопрано, струнних, двох гобоїв і двох 
валторн, «Лісова колискова» для фрлейти, труби, дитячого хору та фортепіано, «Халдеї» для хору хлопчиків, брас-квінтету та ударних).

Поки єдиним театральним твором у доробку є народний балет зі співом балет «Вероніка Десінічка». Однак зацікавлення театром виявлялося вже давно - він $€$ автором музики до вистав «Майстер і Маргарита», «Геркулес», «Романс про три любові» і ще біля десяти постановок. За спогадами композитора, у 1979 році, ще одинадцятирічним хлопчиком, Давор Бобіч як учасник дитячого хору брав участь у виконанні «Страстей за Матвієм» Й. С. Баха на «Барокових вечорах» у Вараждині. Цей виступ залишив слід у його душі, і згодом втілився при створенні його головних вокальносимфронічних творів: ораторії «Король Томислав» та «Ісая», Вуковарський реквієм, кантата «Єрихон». Вагомий і його доробок в галузі хорової музики, зокрема, різноманітна тематика його творів для дитячих хорів. Широка палітра камерно-інструментальних та камерновокальних творів. Композитор, зокрема, розробляє репертуар таких інструментів, як контрабас, фрагот, труба, баян, акордеон, тромбон, туба та інших.

Помітна схильність композитора до програмної музики, різні типи програмності спостерігаємо як серед великих, так і серед камерних творів (Сюїта для симфонічного оркестру «Загорські картини», поема для симфонічного оркестру «Вараждин 1776», «Попелюшка» - цикл для скрипки і фрортепіано, «Нерозказана історія» для фрортепіано та ін.). Серед творів виділяється серія робіт на біблійну тематику. Сюди відносяться ораторія «Ісая», кантата «Єрихон», Концерт для баяна і оркестру «Eschaton», «Голос Єремії» для фрортепіанного тріо, франтазія для органу та ін.

У творчості композитора можна засвідчити артикуляцію національного начала. Це видно і з численних використань сюжетів 
хорватської історії, змалювання образів рідної природи, і зацікавлення музичним фольклором та національною поезією (народний балет зі співом «Вероніка Десінічка», ораторія «Король Томислав», «Меджимурська легенда», Чотири хорватські колядки для хору та оркестру, тріо «Малий Вараждин», вокальна лірика на тексти народних пісень та ін.).

Найхарактернішими рисами музики Давора Бобіча $є$ емоційність, театральність, рельєфність, навіть кінематографрічність образів, які він втілює, використовуючи усе різноманіття засобів виразності сучасності. Палітра образів дуже широка - від апокаліптичних картин, психологічно-заглиблених, драматичних образів до наївно-дитячих картинок з дитячих сюїт для баяна, образів природи. Все ж можна вважати Д. Бобіча композитором гармонійного світовідчуття.

Опуси Бобіча для баяна (акордеона), створені в період останніх 15 років є важливим внеском у збагачення хорватської та світової літератури для цього інструмента. Найбільший твір - концерт під назвою «Eshaton» для баяна і оркестру (прем'єра відбулася у 2002 р.). Концерт має рівноправні партії баяна і оркестру. Це трьохчастинний твір, з інтенсивним розвитком у середній частині, яка демонструє максимум можливостей інструмента. Назва "Eshaton" походить від біблійного «Апокаліпсиса». Темою концерта $€$ «Одкровення Іоанна», тому цей твір можна вважати програмним.

Сміливі ансамблеві поєднання використовує Д. Бобіч, поєднуючи баян 3 віолончеллю та струнним квінтетом у двох Concertinato, 3 симфронічним оркестром у Tango concertante. Ним створено дві серії циклічних творів: дві сонати, три сюїти (Apokalypsis, Kiev, Liturgikal) та чотири дитячі сюїти для інструменту соло, серед яких є цикли 3 узагальненою програмністю. 
Надзвичайно динамічною та інтонаційно цілісною є Соната № 2 «Posthumen» - («Посмертна»). Прем'єра твору відбулася у виконанні автора на випускному екзамені в консерваторії (Київ, 1993 р.). Не зважаючи на чотирьохчастинність, вона інтуїтивно сприймається не як цикл, а як єдина форма із декількома контрастними епізодами.

Найголовнішою рисою драматургії твору $є$ інтонаційна єдність. Інтонації секунди лягли в основу двох тем, що об'єднують, цементують твір. Вони репрезентовані у вступі: перша - вольова, рішуча, основою якої $є$ малосекундовий акцентований мотив. Ця чотиритактова тема компактна, вузькоамбітусна (розгортається у обсязі великої терції), проводиться на фоні кластерних секундових акордів у низькому регістрі, завершується низхідним малотерцовим зворотом. Вона відразу ж занурює слухача у сфреру трагедійно-напружених образів боротьби, вихору життєвих колізій, разом з тим - це образ утвердження та заповзятості. Тема проводиться кілька разів у різних фактурних та гармонічних вирішеннях, що надає їй динамічності, руху.

3 перших тактів сонати виправданою $€$ назва ії першої частини «Токката» - тобто вільного, імпровізаційного жанру, близького до фантазії. В токатах зазвичай використовується багато поліфонічних прийомів, що спостерігається у третьому та четвертому проведенні основної теми. Це ще більше підсилює експресію вступу.

Друга тема вступу (Rubato meno mosso) є не стільки контрастом до першої, як експозицією іншої іпостасі головного образу інтравертної, чуттєвої сторони, внутрішньої інтуїтивної рефрлексії. Друга тема інтонаційно пов'язана із першою - секвентне проведення невеликої низхідної поспівки, в основі якої - мала секунда та тритон на фоні хроматичного руху басів в низькому регістрі створюють атмосферу тривожного очікування, незворотності трагічних подій. 
Ці дві теми вступу репрезентуючи домінуючий образ сонати, є лейтмотивною квінтесенцією, разом з тим, становлять значну частину розвитку драматургії у фріналі та творять лейттематичну арку усього твору.

Головна партія з'являється несподівано після фермати на фоні тривожної терцової репетиції. Характерною особливістю цієї теми є її двоголосна фрактура, тобто композитор продовжує використовувати поліфонічні прийоми, застосовані у вступі. Квінтова інтонація, двічі проведена у різних голосах у високому регістрі звучить як перекличка сигнальних фанфрар, заклик до бою. Другий раз вона звучить двічі зменшеними тривалостями, що надзвичайно динамізує музичну тканину. Інтонаційно головна партія базується на обох темах вступу, однак це лише мотивне вичленовування, поєднане в різноманітних комбінаціях, тобто головна тема сприймається як розробка тематичного матеріалу вступу.

Із проведення басової хроматизованої висхідної поспівки із другої теми вступу на фоні арпеджованих акордів (Energico) починається зв'язкова партія, що теж носить розробковий характер. Побічна партія (т. 59) - це усього лиш невеликий низхідний мотив у обсязі кварти, презентує контрасний, чуттєвий, ліричний образ, що несподівано з'являється у вихорі напруги. Проведення цього мотиву в м'якому середньому регістрі на фоні тремоло вносить у музичну тканину невеликий момент просвітлення. Однак наступне проведення у малій октаві на фоні акордових репетицій (т. 79) повертають драматургію в русло драматичної колізії. Тема починає ламатися, напруга зростає завдяки появі пасажів акцентованих квартових співзвуч із ломаним ритмом, збільшенню динаміки та загальному висхідному регістровому руху фрактури. Експозиція закінчується на вістрі кульмінації. 
Розробка (Misterioso) продовжує напружено-драматичний виклад, однак у нововому, франтастичному ракурсі. Головний герой немов би попадає у полон чар, через які усі його переживання, життєві колізії видаються містичним сном. Для створення цього ефекту використовуються трелі, супровідна репетиція обіймає інтервал малої нони. Поступове згущення фрактури та підвищення регістру готує появу елементів побічної партії, характер якої зовсім змінюється - вона звучить тривожно, напружено (тремоло і в проведення теми і у супроводі). Напруга нагнітається і невелика розробка закінчується ще однією кульмінацією.

Динамічна коротка реприза (т. 135) сприймається як наступний етап боротьби, побудована на темі головної партії, в ній продовжується мотивна розробка матеріалу, разом з тим використані прийоми поліфронії - інтонаційні переклички різни голосів у супроводі тривожних репетицій.

Усі використані у першій частині засоби - інтонаційна єдність, лаконічність тематизму, розробковість, поліфонічні прийоми, токатний репетиційний фон надзвичайно динамізують тканину. Завдяки цим прийомам логічно вибудовується складна драматургія частин, оскільки соната починається не класичною експозицією образів, а теми викладаються у динаміці, тобто потрібна надзвичайна композиторська майстерність, щоб з таким експресивним початком логічно підійти до кульмінації та запобігти драматургічним спадам. Задля цього автор надзвичайно стискає розробку та репризу форми і частина в цілому дійсно набуває рис вільної фантазії, або токати.

Друга частина сонати «Романс» за законами сонатного циклу контрастує із першою та тимчасово відсторонює від сфери основних експресивно-напружених образів. Вона сприймається як чиста, просвітлена мрія, спогад про безтурботні щасливі дні. Основна 
тональність частини ля-мінор, однак починається «Романс» в далекому до-дієз мінорі (що також підкреслює нереальність ситуації) із ніжної мелодії, проведеною у двох голосах, що звучить ніби би душевний діалог між двома люблячими серцями. Друге проведення теми - у ще більш далекому соль-дієз мінорі.

Тема середньої частини інтонаційно споріднена із першою, звучить у ре-мажорі (т. 33) на фроні тремоло тонічного тризвука сприймається як ще один світлий образ, пов'язаний із теплими спогадами. Спочатку тема проводиться одноголосно, а потім розгортається знову як діалог між двома голосами.

В репризі основна тема викладена також двоголосно, у ритмічному збільшенні. Закінчується «Романс» подвійним проведенням низхідного басу, що супроводжував основну тему, це сприймається немов поступове зникнення, розчинення світлого спогаду. Форма «Романсу» - проста тричастинна.

Третя частина «Речитатив» повертає драматургію у русло тривожних, трагічних образів. Назва частини наштовхує на думку, що це тяжка гнітюча сповідь, жаль за втраченим безповоротно. Однак в цьому монолозі відчувається і потаємна сила, бажання боротьби та перемоги.

Вступ у низькому регістрі (повільний висхідний мотив на фоні органного пункту соль) ніби занурює у атмосфреру похмурості чи то підземелля чи можливо старого готичного храму. Невелика п'ятитактова основна тема (інтонаційно пов'язана із першою темою вступу) на фоні органного пункту - це розмірений монолог, однак хроматизовані тризвукові поспівки сприймаються як спалах приглушеної емоції, бажаючи спинити яку оповідач зупиняється...

Знову, збираючись із силами, він починає свою важку розповідь (т. 16, Sostenuto [quasi Grave]) і знову ж охоплений емоціями, замовкає. 
Лише втретє (т. 26) почавши оповідь оповідач не стримує емоцій тризвукова поспівка набуває динамізму, з'являються риси розробковості, що призводить до кульмінаційного проведення основної теми (т. 39). Однак в кінці емоції згасають, знову повертаючи до гнітючого відстороненого стану (т. 46 Grave) образу, що немов би розчиняється у пітьмі.

Форма частини - вільна, структурно перегукується із бароковими токатними композиціями, основою яких імпровізаційне повторення однієї побудови (найчастіше періоду). Очевидно, що така форма якнайкраще відповідає драматургічному задуму автора в цій частина, а саме рельєфному змалюванню одного образу.

Фінал сонати в безповоротному цілеспрямованому вируючому русі немов відкидає все зайве. Це рухається вперед - все швидше і швидше - саме життя, і залишається або злитися із цим рухом, або бути ним зметеним.

Перша тема фріналу - наполеглива, рішуча, інтонаційно споріднена із першою темою вступу першої частини проводиться двома голосами в подвійну октаву, зміна тактових розмірів майже у кожному такті, поєднання дводільних та тридільних ритмічних груп на фоні уривчастих акордів супроводу у швидкому темпі, неочікувані акценти надають їй потужності та непередбачуваності. Друге її проведення захоплює аж три октави, що значно динамізує фрактуру (т.7). Невелика зв'язка, де на передній план виходять синкоповані уривчасті акорди супроводу (т. 20) приводять до наступного епізоду (Meno mosso): терцово-секстові синкоповані співзвуччя та хроматичний хід у високому регістрі, що накладаючись утворює п'ятизвучний кластер нагнітають напруження та готують появу лейттеми усієї сонати - теми вступу із першої частини (Energico). Це торжество основного образу - вольового, рішучого, непереможного начала. 
Після цього невеликий зв'язковий фрагмент на фоні репетиції на ноті соль призводить до кантиленної побічної партії (до-мінор), що інтонаційно апелює до фольклорних наспівів та доповнює групу ліричних образів - побічної партії першої частини та обидвох тем «Романсу».

Нагнітаючі фрактурні прийоми - тремоло, низхідний хроматичний хід, що накладається у звуковий кластер готують нову динамічну хвилю - початок розробки, що будується на інтонаційному матеріалі головної теми сонати, а також тут епізодично з'являються елементи інших тем із першої частини - висхідний хід в басах із другої теми вступу на фроні віртуозних пасажів, що звучать як потужний вихор (т. 115), інтонаційні алюзії побічної партії першої частини (т. 123), та франтастичного розробкового епізоду (т. 132). Це додає музичній тканині контрастних елементів та додаткової експресії. Напруга поступово нагнітається і на кульмінаційному піку у високому регістрі з'являється другий секвенційний елемент головної теми у поліфонічному викладі (т. 156). Завершується соната рішучим утвердженням секундового звороту, що становить основне зерно леттеми (т. 177), а отже перемогою вольового цілеспрямованого начала. Фінал написаний у рондо-сонатній формі.

В цілому соната вражає цілісністю, динамізмом, імпровізаційністю, та в цілому нагадує жанр фантазії. Тканину цементує основна лейттема - що звучить як перша тема вступу, а також головна тема фріналу. Інші теми - друга тема вступу, головна партія першої та третьої частин та перша тема фріналу мотивно з нею пов'язані, що надає твору інтонаційної єдності. Широке застосування розробкових прийомів а також елементів поліфонії сприяє динамічності та цілісності. Цьому допомагає також й вільне застосування сонатної форми, а саме поява елементів розробковості в експозиційних розділах, скорочення репризних частин. Усі ці засоби в комплексі разом 
зі специфічними композиційними, фактурними, ладо-гармонічними, динамічними та іншими прийомами витворюють блискучу неоромантичну драматургію твору.

\section{תimepamypa:}

1. Васильев В. В. Особенности образного строя и музыкального языка в сочинениях для баяна 1970 - 90-х годов / В. Васильев. // Вопросы народно-инструментального исполнительства и педагогики. - Тольятти, Тольяттинский институт искусств, 2002. 2. Григорьева Г. Музыкальные фрормы ХХ века. / Г. Григорьева - М.: Владос, 2004.

3. Имханицкий М. И. Музыка зарубежных композиторов для баяна и аккордеона./ М. И. Имханицкий // - Москва: РАМ им. Гнесиных, 2004.

4. Липс Ф. Р. К вопросу исполнения современной музыки для баяна. / Ф. Р. Липс. // Вопросы професссионального воспитания баяниста. Труды ГМПИ им. Гнесиных. Вып. 48. Отв. Ред. Б. М. Егоров. - М., 2004.

5. Михайлова A. A. Фольклорные и неофольклорные стилевые тенденции в музыке отечественных композиторов для баяна. / A. A. Михайлова. - Саратов, 2002.

6. Олексів Я. Стильова специфріка жанрів сюїти та партити в баянній творчості сучасності. / Я. Олексів // Науковий вісник НАУКМА ім. П. І. Чайковського. Вип.. 10 - ст.. 201-210.

7. Семешко А. Виконавська майстерність баяніста. / А. Семешко // Тернопіль: «Навчальна книга - Богдан», 2009.

8. Сташевський А. Володимир Рунчак "Музика про життя..." Аналітичні есе баянної творчості / А. Сташевський. // - Луцьк: 2004. $-199 c$.

9. www. davorbobic.com 


\section{Refarences:}

1. Vasiliev V. V. Features of the figurative system and the musical language in the works for the bayan of the 1970s - 90s / V. Vasiliev. // Questions of folk-instrumental performance and pedagogy. - Tolyatti, Togliatti Institute of Arts, 2002.

2. Grigorieva G. Musical forms of the XX century. / G. Grigor'eva - Moscow: Vlados, 2004.

3. Imkhanitsky MI Music of foreign composers for accordion and accordion. /M. I. Imkhanitsky // Moscow: RAMS them. Gnessin, 2004.

4. Lips F. R. On the issue of performing modern music for the bayan. / F. R. Lips. // Questions of professional education of the bayanist. Proceedings of GMPI them. Gneiss Yield 48. Otv. Ed. B. M. Egorov. - M., 2004.

5. Mikhailova A. A. Folklore and neo-folklore stylistic tendencies in the music of domestic composers for the accordion. / A. A. Mikhailova. Saratov, 2002.

6. Oleksiy Ya. Style style of the genres of the suite and parties in the bayannnoy creativity of our time. / I. Aleksey // Scientific bulletin of the National Academy of Sciences of Ukraine. P. I. Tchaikovsky. Vip..10 - item .. 201-210.

7. Semeshko A. Performing skill of the bayanist. / A. Semeshko // Ternopil: "Educational book - Bogdan", 2009.

8. Stashevsky A. Volodymyr Runchak "The Music of Life ..." Analytical Essays of Baikon's Creativity / A. Stashevsky. // - Lutsk: 2004. - 199 p.

9. www.davorbobic.com 